\title{
0 oczywistych i nieoczywistych granicach karkonoskich
}

\author{
DOI: 10.19195/2084-4107.11.7
}

\section{Granica realna}

Długi na około 36 km grzbiet główny Karkonoszy tworzy naturalną granicę między terenami, które rozdziela owo najwyższe pasmo Sudetów. Dzisiaj jest to Republika Czeska na południu i Polska na północy, dawniej była to Czechosłowacja oraz po drugiej stronie Niemcy, jeszcze wcześniej Cesarstwo Austrii i Królestwo Prus; zawsze jednak linia ta oddzielała Czechy od położonego na północ od nich Śląska.

W tym kontekście Karkonosze bardzo wcześnie pojawiają się w historiografii obydwu sąsiadujących z sobą krajów. W spisanej po łacinie średniowiecznej kronice niejakiego Galla Anonima (Cronica et gesta ducum sive principum Polonorum, powstałej w latach 1112-1116) wojenna wyprawa polskiego księcia Bolesława Krzywoustego do Czech, połączona z przekroczeniem pogranicznych gór, przyrównana zostaje do słynnego przejścia wojsk Hannibala przez Alpy. Karkonosze uznawano wówczas za niemożliwe do przejścia i zgodnie z tym wyobrażeniem ukazano je w kronice powstałej na początku XII w. jako „nogą ludzką dotąd nietknięte..."1 Odważne, aczkolwiek ryzykowne posunięcie polskiego księcia przyniosło mu przewagę militarną, gdyż zaskoczony nieprzyjaciel nie spodziewał się ataku przeprowadzonego od strony „chmur sięgających, pełnych kamieni i skał, stromych"2 gór.

Pozostaje zagadką, jak w rzeczywistości wyglądała marszruta „polskiego Hannibala" - czy faktycznie przekroczył on góry na wysokości głównego grzbietu, czy też - ku czemu skłania się wielu historyków — podążał raczej przez Bramę Lubawską. Istotne jest tu jednak co innego — pierwsza wzmianka o Karkonoszach jako o obszarze pogranicza, a także kontekst alpejski, pojawiający się w związku z porównaniem jego wyczynu do przejścia Alp przez wojska Hannibala. W późniejszym piśmiennictwie ów kontekst będzie wracał wielokrotnie.

\section{Spór graniczny}

Wydaje się, że późniejsza „kariera” Karkonoszy — także ta turystyczna — ma swoje źródła w sporze granicznym doby nowożytnej. W średniowieczu, gdy wspomniany książę Bolesław ciągnął wraz ze swym wojskiem przez góry, wystarczało stwierdzenie, że granica czesko-śląska (wówczas czesko-polska)

${ }^{1}$ Cyt. za: T. Steć, W. Walczak, Karkonosze. Monografia krajoznawcza, Warszawa 1962, s. 74.

2 Ibidem. 
przebiega gdzieś tam wysoko, prawie wśród chmur, na niedosiężnym grzbiecie najwyższego pasma Sudetów. Jednak później, wraz z postępującym wykorzystaniem gospodarczym tego obszaru - i to po obydwu jego stronach - stało się jasne, że trzeba wreszcie precyzyjnie wyznaczyć granicę. W obliczu faktu, że Karkonosze posiadają w zasadzie dwa grzbiety główne - Czeski i Śląski, które przebiegają równolegle do siebie, ostateczne ustalenie linii oddzielającej obydwa kraje stało się kwestią wielce problematyczną.

W wieku XVI rozpoczął się spór graniczny między czeskimi (Harrachowie) a śląskimi (Schaffgotschowie) właścicielami ziemskimi, których latyfundia leżały po obu stronach gór. Ślązacy najchętniej widzieliby przebieg granicy na Grzbiecie Czeskim, a panowie czescy naturalnie - na Śląskim. Centralne znaczenie miało przy tym ustalenie, który obszar uznany zostanie za źródlisko Łaby: czy będzie to łąka między Violíkiem³ a Kotlem (a więc obszar noszący dziś nazwę Labskiej louki), czy też Bílá louka u podnóża Śnieżki. Z tego powodu obydwa te punkty na mapie owego obszaru granicznego stały się miejscem manifestacji politycznych i religijnych — była to konsekracja kaplicy św. Wawrzyńca na szczycie Śnieżki, przeprowadzona przez krzeszowskiego opata Bernharda Rosę w 1681 r., i poświęcenie źródeł Łaby, dokonane przez biskupa Hradca Králové, Johanna Franza Christopha von Talmberga w $1684 \mathrm{r}$.

Kaplica ufundowana przez hrabiego Christopha Leopolda Schaffgotscha stała się z czasem celem licznych pielgrzymek, w których uczestniczyła zarówno ludność lokalna, jak i goście przebywający na kuracji w Cieplicach Śląskich-Zdroju. To z kolei stanowiło właściwy początek turystyki w śląskich Karkonoszach, podobną rolę odgrywały źródła Łaby po stronie czeskiej; w XIX w. obecność tych dwu istotnych punktów na mapie gór - Śnieżki i Labskiej louki — odegra fundamentalne znaczenie w kontekście rozwoju turystyki masowej.

Rola grzbietu Karkonoszy jako naturalnej granicy, ukazana już w Cronica et gesta ducum sive principum Polonorum, podkreślona zostanie w literaturze doby nowożytnej. Sam wielki Martin Opitz von Boberfeld, „ustawodawca” barokowej poezji niemieckiej, rozpoczyna swoje dzieło Schäfferey von der Nimfen Hercinie (Idylla o nimfie Hercynii $\left.{ }^{4}, 1630\right)$ tymi słowy:

Po tej stronie sudeckiej krainy, która oddziela Czechy od Śląska, leży u stóp uroczych Karkonoszy dolina, która rozpościera się szeroko na podobieństwo półkola, a wypełniają ją liczne wieże wysokie, potoki piękne, wsie, folwarki i owczarnie ${ }^{5}$.

${ }^{3}$ Nazwanym po polsku Łabskim Szczytem.

${ }^{4}$ Przy pierwszej wzmiance o utworze niemieckim nieprzełożonym na polski w nawiasie umieszczona zostanie propozycja tłumaczenia tytułu danego dzieła na nasz język; w dalszej części tekstu używana będzie już tylko nazwa polska.

5 M. Opitz, Schäfferey von der Nimfen Hercinie [1630], red. P. Rusterholz, Stuttgart 1969, s. 9. Wszystkie cytaty w przekładzie autora niniejszego artykułu. 
Owa piękna kraina znajduje się po ,tej stronie sudeckiej krainy” — a więc na Śląsku, podczas gdy widziane z Karkonoszy Czechy jawią się jako obszar, z którego spodziewać się można niebezpieczeństw zagrażających tej uroczej okolicy:

Owe to pola są, tam kraj ten leży, co

Płomieniem strzela wzwyż, który przynosi zło ${ }^{6}$.

Oczywiście należy tu uwzględnić specyficzne położenie Opitza, który przebywał na kuracji w Cieplicach Śląskich-Zdroju na zaproszenie barona Hansa Ulricha Schaffgotscha (ojca Christopha Leopolda). Ów śląski arystokrata, któremu notabene poeta zadedykował swój utwór Idylla o nimfie Hercynii ${ }^{7}$, był jedną ze stron we wspomnianym sporze granicznym - adwersarzem Schaffgotscha był czeski hrabia Harrach. Nie dziwi więc, że kraina kojarząca się z przeciwnikiem barona, z którego szczodrobliwości korzystał Opitz, odmalowana została w nieprzychylnych słowach niosących skojarzenia z piekłem. Trudno też nie zauważyć tu kontekstu wojny trzydziestoletniej; jeśli uwzględnić późniejszy, tragiczny los Hansa Ulricha Schaffgotsch, który w wyniku owego konfliktu zbrojnego stracił życie i majątek, słowa Opitza odczytać można niemalże jak proroctwo. Niestety, wysokie góry nie były w stanie potrzymać okropieństw wojny, która z Czech rozlała się na Śląsk:

A oto Czeski Las, Sudety zwie się go;

I choć wysoki jest, to jednak strach i zło

Frunęły ponad nim. Naturo, ty nasz dom,

$\mathrm{Na}$ darmo oddzieliłaś od tamtych wrażych stron ${ }^{8}$.

Jednakże istotny wydaje się też fakt, że poeta podkreśla tu rolę Karkonoszy jako naturalnego wału granicznego, co wielokrotnie pojawiać się będzie także u późniejszych autorów.

\section{Granica polityczna}

Po pierwszej wojnie śląskiej, a więc po 1742 r., granica przebiegająca przez Karkonosze i Góry Izerskie zyskała na znaczeniu. O ile wcześniej rozdzielała ona dwa kraje będące częścią pozostającej pod rządami Habsburgów Korony Królestwa Czech, o tyle po wojnie oddzielała pruski już Śląsk od Czech, które nadal pozostawały pod berłem dynastii pochodzącej z Austrii. Pewien ewangelicki duchowny z Berlina, Jakob Elias Troschel, który podróżował przez najwyższe pasmo Sudetów w 1783 r., a więc już sporo po zakończeniu wojny siedmioletniej, podkreśla w przedmowie do relacji ze swej podróży graniczny charakter owej okolicy:

Tak wspaniała, szwajcarska okolica tylko niecałe 40 mil od Berlina, tak ciekawa dla tych, którzy potrafią dostrzec piękno i potęgę natury,

\footnotetext{
${ }^{6}$ Ibidem, s. 52.

7 Por. ibidem, s. 5.

8 Ibidem, s. 53.
} 
najwyższe góry Niemiec, które dotychczas znałem prawie wyłącznie $\mathrm{z}$ gazet wojennych, jako przerażającą, prawie nieosiągalną barierę między Śląskiem a Czechami, mające oblicza tak rozmaite, miejsca strasznie piękne, rajskie łąki między nagimi, sięgającymi nieba skałami, będące siedzibą pracowitości i skromności, ale równocześnie kwitnącej działalności, były mi tym bardziej godne obejrzenia, a dziwiło mnie jedynie, że żaden z tamtejszych mieszkańców nie uznał, że warto by kiedyś podjąć się trudu opisania dziwów tych okolic ${ }^{9}$.

Uwagę zwraca tu zwłaszcza porównanie ze Szwajcarią, a więc z państwem, które automatycznie wywołuje skojarzenia alpejskie - śląsko-czeskie Karkonosze stylizowane są tu na rozleglejsze i wyższe Alpy.

Kilka lat wcześniej, jeszcze w czasie trwania wojny siedmioletniej, powstało dzieło, które uchodzi dziś za pierwszy kompletny opis przyrodniczy Karkonoszy. Autor tej pracy, niegdysiejszy proboszcz ewangelicki z Piechowic u stóp Karkonoszy i późniejszy kaznodzieja kościoła św. Elżbiety we Wrocławiu, Johann Tobias Volkmar, opierał się na rozprawach wybitnego szwajcarskiego przyrodoznawcy i badacza, Johanna Jacoba Scheuchzera. Dzieło śląskiego duchownego ukazywało się pierwotnie pod tytułem Beruhigungen des Herzens bey äuserlichen Weltunruhen durch allerley nützliche und gottselige Betrachtungen (Serca ukojenia w czas niepokoju na świecie przez wszelakie rozważania pożyteczne a nabożne), w 1760 r. drukował je w odcinkach jeden z jeleniogórskich tygodników; utwór znany dziś jako Reisen nach dem Riesengebirge (Podróże ku Karkonoszom) ukazał się w praktycznie niezmienionym wydaniu książkowym w 1777 r. nakładem bolesławieckiego wydawnictwa Drukarnia Sierocińca.

Wówczas, w 1760 r., dystansując się od wojennej zawieruchy, autor ulatywał na wyżyny grzbietu Karkonoszy, szukając schronienia i pociechy u Boga i natury. Wędrując po wierzchowinie najwyższego pasma Sudetów, rzeczowo i bez zbędnej egzaltacji, którą zwykle cechował się jego styl, opisał drogę graniczną oddzielającą Czechy od Śląska. Co ciekawe, duchowny ograniczył się tu jedynie do lokalnego, czesko-śląskiego, wymiaru owej linii, przemilczając kontekst ogólnoeuropejski, konsekwentnie milcząc o strefach wpływu Austrii i Prus lub też — co w zasadzie byłoby tu dużo bardziej adekwatne — dynastii Hohenzollernów i Habsburgów. Volkmar pisze:

Wysoko w górze znaleźć można specjalnie wytyczoną ścieżkę, którą zwie się granicą, gdyż wszystko, co znajduje się na prawo ${ }^{10}$ od niej należy do Czech, a na lewo do Śląska. Podróżny zauważy, iż wielcy panowie, do któ-

9 J[akob]. E[lias]. T[roschel]., Reise von Berlin über Breslau nach dem schlesischen Gebirge im Sommer 1783 [von J.E.T.] (Podróż J.E.T.-a z Berlina przez Wrocław ku ślaskim górom latem 1783 roku), Berlin 1784, s. 1-2.

10 Marszruta opisana przez Volkmara prowadzi przez główny grzbiet Karkonoszy ze Szklarskiej Poręby w stronę Śnieżki, a więc z zachodu na wschód; z perspektywy wędrowca północ znajduje się po jego lewej, a południe po prawej ręce. 
rych należy ta kraina, przy wytyczaniu tej granicy trzymali się reguły, że gdzie jakaś góra skłania się ku Śląskowi, winna być śląska, gdzie zaś się skłania ku Czechom, winna być czeska; jeśli się tym kierować, to nawet, gdy wędruje się przez długie mile po szerokiej równi i zgubi się tę ścieżkę, czyniąc tysiące kroków po nagich kamieniach, gdzie nie widać drogi, to w węższych miejscach łatwo znów ją odnaleźć, gdyż zawsze to najwyższy grzbiet czyni granicę ${ }^{11}$.

Jedenaście lat później, jako swego rodzaju czeska odpowiedź na neutralny opis Ślązaka, powstała publikacja, której autorem był mieszkający po południowej stronie gór Franz Fuß — zarządca należącego do hrabiego Morzina majątku Vrchlabí. Swoje dziełko napisał na zlecenie Czeskiego Towarzystwa Naukowego, nosi ono tytuł Versuch einer Topographischen Beschreibung des Riesengebirges, mit Physikalischen Anmerkungen (Próba topograficznego opisu Karkonoszy, wraz z uwagami fizykalnymi), a ukazało się drukiem w Dreźnie w 1788 r. Podobnie jak czynił to niegdyś śląski poeta Opitz, Fuß próbuje zdyskredytować w swym opisie kraj po przeciwnej — „wrogiej” — stronie gór. Owego zabiegu dokonuje tym razem w odniesieniu do „hrabiowskiego gniazda Schaffgotschów, chylącego się ku ruinie zamku zwanego Chojnik [...], który stoi na skale i pierwotnie pewnie miał się oprzeć wieczności"12 — podkreślając obecną ruinę tej niegdyś dumnej rezydencji, autor w zawoalowany sposób podważa splendor śląskiej rodziny.

Podobną strategię, tym razem znów w odniesieniu do strony czeskiej, stosuje wielokrotnie inny autor, którego przywołamy tu jako ostatniego przedstawiciela oświecenia. Jest to urodzony 9 sierpnia 1759 r. w Quedlinburgu pedagog Johann Christoph Friedrich GutsMuths, który — działając w słynnym ,zakładzie wychowawczym" w Schnepfenthalu - wprowadził do programu nauczania niemieckich szkół wychowanie fizyczne. Dnia 11 maja 1796 r. rozpoczął on swą sześciotygodniową wędrówkę, którą opisał później w złożonym z fragmentów listów sprawozdaniu. Ogłoszone anonimowo dzieło nosi iście barokowy tytuł: Meine Reise im deutschen Vaterlande, aus Thüringen ins Riesengebürge zu den Elbquellen und durch Böhmen ins Erzgebürge; über Erfurt, Leipzig, Dresden, Bautzen, Görlitz, Bunzlau, Warmbrunn, Hirschberg, Arnau, Turnau, Prag und Töplitz bis Freyberg (Moja podróż po niemieckiej ojczyźnie, z Turyngii w Karkonosze do źródet Łaby i przez Czechy w Rudawy, przez Erfurt, Lipsk, Drezno, Budziszyn, Zgorzelec, Bolesławiec, Cieplice Śląskie-Zdrój, Jelenią Górę, Hostinné, Turnov, Pragę i Teplice aż do Fryburga Saskiego). Jako miejsce publikacji na karcie tytułowej podane zostają m.in. Jelenia Góra i Wrocław — główna siedziba wydawnictwa Korna, które wydrukowało ową pozycję w 1799 r. Także i tutaj

11 J.T. Volkmar, Reisen nach dem Riesengebürge, Bunzlau 1777, s. 39-41.

12 F. Fuß, Versuch einer Topographischen Beschreibung des Riesengebirges, mit Physikalischen Anmerkungen, [Der Böhmischen Gesellschaft der Wissenschaft gewidmet, von..., Gräfl. Morzinischen Oekonomie-Direktor], Dresden 1788, s. 31. 
pojawiają się informacje o granicy w Karkonoszach, zrazu neutralne, niczym u Volkmara, później jednak połączone z refleksjami natury politycznej:

Od Śnieżki, grzbietem najwyższych gór, przebiega zacna granica świętej rzeszy niemieckiej. Wzdłuż naszej drogi widzieliśmy granitowe piramidy i kawałki skał służące za kamienie graniczne. W innych miejscach zaznaczono ją przecinkami w kosodrzewinie. Gdybyż tak były owe szare góry, przez które przebiega, symbolem trwałości granic naszej rzeszy, ach jakże faktycznie święte [= zbawione] byłby Niemcy! Tak myślałem, patrząc ku zachodowi, gdzie właśnie słońce poczęło się chylić, wspominając dumny naród [francuski], który opętany rządzą władzy w poszerzaniu swych granic widzi rekompensatę za poniesione koszta wojny ${ }^{13}$.

Jednak dużo ciekawszy niż opis samej granicy zda się obraz obydwu krajów leżących po dwóch stronach grzbietu Karkonoszy. Autor, w wielu miejscach dający się poznać jako przekonany zwolennik Prus i wyznawca Fryderyka II Wielkiego, w następujący sposób przedstawia widok ze Śnieżki w stronę Śląska i Czech, całkowicie wpisując się w tendencję zapoczątkowaną niegdyś przez Opitza, a nawet przebijając jego sądy:

Po południowej, czeskiej stronie góry łagodnie opadają ku nizinie. Nie widać tam więc żadnych zamieszkanych miejsc; po stronie śląskiej leżą natomiast niezliczone wsie, a także Jelenia Góra, Kowary, Kamienna Góra, Podgórzyn, Chojnik ${ }^{14}$.

Dzikie, niecywilizowane Czechy dla lepszego kontrastu zestawione zostają z cywilizowanym, zagospodarowanym Śląskiem. By dodatkowo wzmocnić ten efekt, autor zdaje się patrzeć mimo Pragi, ponad nią, ku związanej wówczas z Hohenzollernami Frankonii, której góry wydaje mu się dostrzegać:

Przy naprawdę jasnej pogodzie można ponoć dojrzeć Pragę. Nie wiem, czy to możliwe, gdyż owo miasto położone jest w dolinie; ale ponad Praga patrzyłem ku Frankonii, widziałem jasnoszare góry, które zdały mi się bardzo odlegle. Że widać nie tylko Landskronę nieopodal Zgorzelca, ale także szerokie połacie Łużyc i w ogóle niezwykle daleko na północ i północny wschód, jest zupełnie oczywiste ${ }^{15}$.

Nie dziwi też, że w relacji z podróży GutsMuthsa nieprzyjemny, zimny wiatr wieje właśnie od strony czeskiej. Tak dzieje się np. na niebezpiecznej krawędzi Śnieżnych Kotłów:

13 [Johann Christoph Friedrich GutsMuths], Meine Reise im deutschen Vaterlande, aus Thüringen ins Riesengebürge zu den Elbquellen und durch Böhmen ins Erzgebürge; über Erfurt, Leipzig, Dresden, Bautzen, Görlitz, Bunzlau, Warmbrunn, Hirschberg, Arnau, Turnau, Prag und Töplitz bis Freyberg, Breslau, Hirschberg, Lissa in Südpreußen 1799, s. 150-151.

14 Ibidem, s. 144.

15 Ibidem, s. 145. 
Rząd skał, niczym jęzor sięgający od środka najwyższej krawędzi dość daleko ku przepaściom, dzieli ją na dwie części, tworząc wielki i mały Śnieżny Kociot. Staliśmy wysoko na krawędzi, gdzie jeszcze leżał głęboki śnieg, plecami opierając się wiejącemu z Czech straszliwemu orkanowi, który groził nam zepchnięciem w przepaść, i patrzyliśmy w dół; z górnej krawędzi niepodobna objąć wzrokiem całego wgłębienia, jeśli nie jest się zupełnie szalonym i nie chce się przesadnie ryzykować, wdrapując się na najdalszą krawędź; przynajmniej dziś dujący wiatr czynił to zupełnie niemożliwym ${ }^{16}$.

Nie inaczej przedstawiał się ów straszliwy czeski wiatr podczas wspinaczki z Równi pod Śnieżką na najwyższy szczyt Karkonoszy:

Wiatr dął mocno i zimo z Czech, wciskał się w Obří důl i mknął w górę po stromej skalnej ścianie, wiejąc prosto w nasze twarze ${ }^{17}$.

Znajdujący się już po czeskiej stronie Obří důl nie sprawia przyjemnego wrażenia. W opisie wyraźnie można dostrzec słowa niosące negatywne skojarzenia (przepaść, paszcza, diabeł, także wspomniany już zimny wiatr), które — jak ukazuje też powyższy fragment — zestawione zostają z Czechami:

Wysoko wzdłuż przeraźliwej krawędzi wznoszą się poszarpane skały w rozmaitych kształtach, niczym zębiska potwornej paszczęki. Ta straszliwa przepaść nazywa się Obři důl albo Dót Diabelski ${ }^{18}$.

O ile śląska strona Karkonoszy jawi się jako względnie zagospodarowana i ucywilizowana - co już zostało wspomniane, w opisie GutsMuthsa czeska część gór jest przedstawiona w roli zupełnego odludzia. Autor ukazuje to podkreślając np., że był pierwszym, który odważył się zejść w straszliwy Labský důl. Takiej informacji udzielił mu doświadczony przewodnik prowadzący turystów przez góry, który był prawdziwie przerażony, gdy głodny wiedzy i przygód klient upierał się, by podążyć za tokiem Łaby w tę straszliwą przepaść. Krawędź Labskiego dolu jest bowiem szczególnie zdradliwa:

Zwie się tę dolinę Labskim dolem. Z góry wygląda wcale ładnie, widać porastające go pojedyncze drzewa przemieszane na zmianę z łączkami, które zdają się zachęcać do spacerów; ale biada temu, kto się na taki spacer wybierze; nie znam straszliwszej doliny ${ }^{19}$.

Być może oświeceniowy „wuefista” chciał dorównać swym wyczynem samemu wielkiemu Goethemu, któremu przypisuje się pierwsze wejście na Brockem

\footnotetext{
16 Ibidem, s. 152.

17 Ibidem, s. 143.

18 Ibidem.

19 Ibidem, s. 167.
} 
w warunkach zimowych (10 grudnia 1777 r.). GutsMuths podkreśla bowiem ogromne trudności natury technicznej, towarzyszące zejściu w głąb Labskiego dolu.

\section{Granica wyznaniowa}

W relacji quedlinburczyka Karkonosze ukazane zostają jako granica między dwoma różnymi od siebie krajami — cywilizowanym a dzikim. Autor tendencyjnie stylizuje je także na granicę wyznaniową, choć zabieg ów wydaje się mocno naciągany wobec faktu, że szerokie rzesze ludności zamieszkującej śląską część gór, będącą w posiadaniu katolickich Schaffgotschów i krzeszowskich cystersów, należały do Kościoła Rzymskiego. Niemniej GutsMuths stwierdza:

Gdy przy jednej z bud zapytaliśmy jakąś starą babinę o drogę i otrzymaliśmy odpowiedź: „tam, gdzie nasz Pan Bóg pod lasem stoi”, zorientowałem się z tej wskazówki, że znajdujemy się już na duchownym terenie papieża. Aż żal mi się zrobiło tych małych wdzięcznych chłopców i dziewcząt biegających wokół, którzy swoje wyobrażenie o Bogu czerpią z owego paskudnie wypacykowanego suchego ludzika ${ }^{20}$.

\section{Pruski powieściopisarz w Karkonoszach}

Między rokiem 1868 a 1892 „marchijski poeta” Theodor Fontane, autor wielu tzw. powieści berlińskich, przebywał jako urlopowicz w Karkonoszach w sumie aż 10 razy. Spędzając letnie miesiące w Mysłakowicach, Sobieszowie, Karpaczu, a na koniec także w Karpaczu Górnym, pisarz nie tylko odpoczywał, lecz także pracował nad nowo powstającymi dziełami, które jednak sporadycznie zajmowały się tematem śląskich gór. Jednym z nielicznych, i choćby dlatego interesującym, przykładem jego utworu, w którym przedstawione zostały najwyższe góry Śląska i Czech oraz ich mieszkańcy, jest powieść Quitt (Kwita), która po raz pierwszy ukazywała się w skróconej i uproszczonej wersji na łamach renomowanego lipskiego żurnalu „Die Gartenlaube” w kilku odcinkach między styczniem a marcem 1890 r.; pełne wydanie książkowe ogłoszono drukiem w tym samym roku w wydawnictwie Friedricha Fontane - syna autora. Akcja tego utworu, podobnie jak większości innych dzieł „marchijskiego poety”, bazuje na autentycznym wydarzeniu, które dla uzyskania odpowiedniego efektu zostało przez pisarza nieco zmodyfikowane. W tym wypadku bohaterami opowiedzianej historii są młody kłusownik i przemytnik imieniem Lehnert Menz i jego „naturalny” wróg - leśniczy Opitz. Nie wdając się teraz w szczegóły akcji tej powieści, której poświęcono już dość rozpraw i przyczynków komentujących i interpretujących owo dzieło, spójrzmy na jeden fragment, który wydaje się istotny w kontekście niniejszego szkicu.

20 Ibidem, s. 175. 
Protagonista (Menz) spotkał swojego antagonistę (Opitza) na górskiej ścieżce między (Małą) Kopą a obecną Strzechą Akademicką, doskonale wiedząc, że urzędnik będzie tamtędy przechodził. W zasadzie całe spotkanie było specjalnie zaaranżowanym przez Menza „sądem bożym”. Widząc przed sobą zamaskowaną postać, w której jednak nie rozpoznał kłusownika, leśniczy chciał strzelić, ale służbowa broń zawiodła, prawdopodobnie z powodu wilgoci. Na jego nieszczęście strzelba głównego bohatera powieści okazała się sprawna i zadziała, Opitz został postrzelony i, umierając, zanotował na kartce papieru:

Postrzelono mnie koło dziewiątej... Jeśli umrę, nim zostanę odnaleziony, niech będzie wiadomo, że strzelił do mnie jakiś kłusownik, był bardzo blisko, miał dwururkę, brązowy płaszcz i kapelusz, i sztuczną brodę, był wysoki, prawdopodobnie Czech... ${ }^{21}$

Abstrahując od dalszego rozwoju akcji, która po owym zdarzeniu nabiera tempa, warto zwrócić uwagę na jeden fakt: osoba obca i zagrażająca leśniczemu uzbrojony kłusownik — od razu postrzegana jest jako obcy, jako „Czech”. Zbrojny intruz nie jest ,tubylcem” lecz kimś ,zza miedzy”. Polityczna granica stanowi równocześnie linię oddzielającą świat znany, bezpieczny od obcego i przynoszącego niebezpieczeństwo. Tak przynajmniej myśli bohater powieści — jedynie czytelnik i oczywiście wszechwiedzący narrator wiedzą, że leśniczy się myli.

Innym utworem Theodora Fontane, w którym wymieniona zostaje granica, jest krótkie opowiadanie pod tytułem Eine Nacht auf der Koppe (Noc na Śnieżce) z 1893 r., które wraz z trzema innymi tekstami tworzy cykl Aus dem Riesengebirge. Kleine Geschichten (Z Karkonoszy. Historyjki). W tym objętościowo skromnym dziełku przedstawione zostają liczne rytuały ery turystyki masowej, w tym słynna już obserwacja wschodu słońca ze szczytu Śnieżki. W przyprawionym subtelną ironią opowiadaniu autor ukazuje szeroki repertuar zabaw mocno rozochoconych pruskich turystów, do którego należy m.in. polonez prowadzący ze śląskiego schroniska na czeską stronę góry, połączony z dość osobliwą manifestacją polityczną: na czeskiej połowie platformy szczytowej, pozostającej we władaniu Habsburgów, trzykrotnie wzniesiony zostaje okrzyk na cześć cesarza Niemiec - Wilhelma ${ }^{22}$. To właśnie obecność granicy państwowej umożliwia podchmielonej publiczności, typowym przedstawicielom nowoczesnego społeczeństwa hołdującego beztrosce i zabawie, poszerzenie repertuaru coraz bardziej żałosnych, wręcz głupkowatych turystycznych rytuałów, będących już tylko marnym cieniem pełnego niegdyś wzniosłości obserwowania wschodu słońca symbolu oświecenia.

21 T. Fontane, Quitt, [w:] idem, Romane und Erzählungen in acht Bänden, red. P. Goldammer et al., t. 5, Berlin-Weimar 1973, s. 369.

22 Por. T. Fontane, Eine Nacht auf der Koppe, [w:] idem, Von, vor und nach der Reise, [w:] idem, Sämtliche Werke, red. E. Gross et al. [NFA — »Nymphenburger Fontane-Ausgabe «], München 1975, t. 18. (Unterwegs und wieder daheim), s. 89.

Góry, Literatura, Kultura 11, 2018

(C) for this edition by CNS 


\section{Granica obyczajowa (i zmysłowa)}

Opuśćmy teraz wiek XIX, by zajrzeć do powieści opublikowanej w 1902 r., która swego czasu stała się wielkim bestsellerem. Ponieważ jest to dzieło autora dziś nieco zapomnianego, przedstawmy pokrótce jego sylwetkę. Paul Keller urodził się 6 lipca 1873 r. w Milikowicach — wsi leżącej mniej więcej w połowie drogi między Jaworzyną Śląską a Świdnicą; jego ojciec był murarzem i drobnym kupcem. Przyszły pisarz wyuczył się solidnego zawodu, podobnie jak wielu śląskich pisarzy owego czasu był z wykształcenia nauczycielem. W latach 1887-1890 uczęszczał do preparandy w Lądku-Zdroju w dawnym hrabstwie kłodzkim, by później przez sześć semestrów kontynuować naukę w seminarium nauczycielskim we Wrocławiu. Pierwszą posadę otrzymał w Jaworze, po ośmiu miesiącach trafił do preparandy w Świdnicy w charakterze nauczyciela pomocniczego. Po dwóch latach powrócił do Wrocławia, gdzie pracował w różnych szkołach powszechnych.

Ostatecznie w 1908 r. porzucił karierę nauczyciela, poświęcając się pracy pisarza i wydawcy. Pod względem ilościowym dzieło Kellera przedstawia się wcale pokaźnie; do najbardziej znanych jego powieści należą (w porządku chronologicznym): Die Heimat (Ojczyzna, 1903), wielokrotnie wznawiana powieść Der Sohn der Hagar (Syn Hagar, 1907), dalej Das Niklasschiff (Statek Mikołaja, 1907), Die alte Krone (Stara korona, 1909) oraz Die fünf Waldstädte (Pięć leśnych miast, 1910). Wielką popularnością cieszył się swego czasu utwór zatytułowany Ferien vom Ich (Wakacje mojego Ja, 1916), który aż trzy razy posłużył za kanwę produkcji filmowej (w latach 1934, 1952 i 1963). Poszczególne opowiadania Kellera pojawiały się w przekładach na 17 różnych języków, w tym czeski, fiński, węgierski, a także polski. W historii śląskiego piśmiennictwa autor znany jest nie tylko jako odnoszący spore sukcesy twórca licznych powieści i opowiadań, ale także jako założyciel miesięcznika „Die Bergstadt”, który wydawał w latach 1912-1931. Warto podkreślić, że postać redaktora, dziennikarza czy pisarza bardzo często pojawia się też w jego utworach; nierzadko w roli protagonisty i zarazem pierwszoosobowego narratora.

Tak też jest w wypadku debiutu powieściowego Kellera - Waldwinter (Leśna zima) — to jest właśnie ów wspomniany już bestseller, któremu teraz poświęcimy kilka słów. Treścią utworu jest sympatyczna, z dzisiejszej perspektywy nieco naiwna historia pewnego pisarza, który - uciekając od zgiełku wielkiego miasta (Wrocławia?) — zaszywa się w częściowo zrujnowanym, ale jednak zamieszkałym zamczysku w górach; z opisów obiektu łatwo się domyślić, że pierwowzorem dla powieściowej warowni jest zamek Grodno koło Zagórza Śląskiego. Oczywiście nasz bohater wplątuje się w historię miłosną, a najważniejszy jej akt, będący równocześnie dosłownie i w przenośni punktem kulminacyjnym utworu, rozegra się na szczycie Śnieżki w śniegach grzbietu śląskich i czeskich Karkonoszy. To właśnie na wierzchołku królowej Sudetów protagonista wyznaje 
swą miłość głównej postaci kobiecej. Następnie bohaterowie udają się w szaleńczą eskapadę narciarską przez zaśnieżone doliny i grzbiety czeskiej strony gór, by na końcu pobłądzić we mgle i całej historii nieomal nie przypłacić życiem.

Należy przy tym podkreślić, że śląski autor w opisie owej narciarskiej przygody jest bez porównania celniejszy niż noblista z Lubeki, Thomas Mann. $\mathrm{O}$ ile sceny z zimowej wyprawy Hansa Castorpsa z pewnością należą do najsłabszych fragmentów Czarodziejskiej góry, o tyle przedstawiona przez Kellera jazda przez zaśnieżone Karkonosze jest plastyczna i w pełni przekonująca autor sam był doświadczonym narciarzem. Topografia „zgadza się” i choć trasa wycieczki jest naprawdę nader śmiała i niezwykle długa, to jednak mieści się ona w realistycznych ramach. Para bohaterów opuszcza rankiem Špindlerovą boudę, przez Mały Szyszak podąża na Równię pod Śnieżką i dalej na wierzchołek najwyższego szczytu Sudetów, gdzie dochodzi do wspomnianego już wyznania. $\mathrm{Z}$ powodu, który czytelnik pozna dopiero $\mathrm{w}$ dalszej części powieści, bohaterka uznaje wpierw, że nie może przyjąć miłości protagonisty i rusza w najwyraźniej samobójczy zjazd w Obří důl, zostaje jednak dognana przez swego partnera narciarskiego - a równocześnie narratora - i przekonana, by wrócić na grzbiet, do nieistniejącego już dziś Schroniska Księcia Henryka, gdzie przebywa reszta towarzystwa.

Jednak podczas dalszej jazdy z Peca pod Sněžkou ku Luční i Studniční horze, na przełęczy między tymi obydwoma szczytami, gdzie dziś mieści się kaplica ku czci ofiar gór, para narciarzy zostaje zaskoczona przez mgłę i gubi drogę. Wyczerpani, bohaterowie zamarzając, ogrzewają się wzajemnie i w obliczu śmierci kobieta wyznaje swoją miłość do protagonisty. W śmiałej jak na Kellera, erotycznej, choć dyskretnie niedopowiedzianej scenie zamarzania zasugerowane zostaje zbliżenie pary, która po zaspokojeniu swoich pragnień wydaje się skazana na śmierć w śnieżnej pustce Karkonoszy. Słysząc zbliżające się dźwięki rogów, w które dęło się dając znaki zagubionym we mgle, bohaterka wzbrania się początkowo, by wołaniem wskazać swe położenie, chcąc się poświecić w imię przyzwoitości. Jednakże pełen chęci życia protagonista odzywa się dość głośno, by para została uratowana. Co ciekawe, bohaterka zdecydowanie odrzuca propozycję ratowników, by przenocować w Luční boudzie, choć zrobiło się już naprawdę późno. Po krótkim odpoczynku para udaje się — mimo ogromnego zmęczenia — do Schroniska Księcia Henryka po śląskiej, pruskiej stronie Karkonoszy.

Czeska strona gór jest właśnie tą, na której dochodzi do przekroczenia granic obyczajowych (i zmysłowych). Coś, co byłoby nie do pomyślenia po przyzwoitej pruskiej stronie, dokonuje się na dzikiej ziemi czeskiej (a w zasadzie śniegu). Pojawia się tu więc jeszcze jeden wymiar graniczności Karkonoszy.

Co ciekawe, w filmowej wersji Leśnej zimy, produkcji wytwórni UFA z 1936 r. z Hansi Knoteck i Viktorem Staalem w rolach głównych, motyw przekroczenia granicy zostaje całkowicie pominięty, choć akcja pierwszej ekranizacji toczy się na Śląsku i w Karkonoszach (w drugiej adaptacji z 1956 r. przedstawione wydarzenia przeniesione zostają $\mathrm{w}$ Las Bawarski). Scenariusz przygotowany przez 
Curta Johannesa Brauna i Fritza Petera Bucha ma niewiele wspólnego z topograficzną dokładnością pierwowzoru literackiego, w samej akcji zastosowano też wiele skrótów, uproszczeń i zmian. Jedynie pewne poszlaki, w tym autentyczne plenery, pozwalają domyślić się, że fabuła przedstawiona zostaje na tle krajobrazu gór ówczesnego wschodu Niemiec. W zasadzie równie dobrze jak Karkonosze mogłyby to być Rudawy lub Szumawa.

Fakt, że akcja rozgrywa się w rejonie przygranicznym, wynika wyłącznie $\mathrm{z}$ jednorazowej wzmianki o pogranicznikach, padającej w jednym z dialogów. I choć na ekranie pojawia się nieistniejące już Schronisko Księcia Henryka, postaci występujące w filmie mówią jedynie o „grzbiecie”, nazwa Karkonoszy nie pada ani razu. Jeśli weźmie się pod uwagę datę powstania filmu, dwa lata przed dyktatem monachijskim, można przypuszczać, że przemilczenie faktu istnienia granicy mogło wiązać się z dążeniami do aneksji tzw. Kraju Sudeckiego. Jednakże, choć wydaje się to wielce prawdopodobne, pozostaje jedynie w sferze przypuszczeń.

\section{Granica między światami}

Występująca w powieści Leśna zima granica „obyczajowa (i zmysłowa)” nie jest bynajmniej ostatnią z możliwości, które można wymienić w kontekście najwyższego pasma Sudetów. Na zakończenie można tu przytoczyć dzieło, które z punktu widzenia całości badań nad literaturą karkonoską jawi się raczej jako zjawisko marginalne. To libretto pióra Georga Döringa do romantycznej opery Louisa Spohra Der Berggeist (Duch Gór, powstała w 1824, premiera 24 marca 1825 r. w Kassel). W utworze tym Karkonosze ukazane są jako granica między tym a tamtym światem - między dziedziną ludzi i duchów. W historii swobodnie operującej motywami licznych opowieści o Duchu Gór (Krakonošu, Rübezahlu), zapośredniczonymi dzięki dziełom Johannesa Praetoriusa i Johanna Karla Augusta Musäusa, a będącej w gruncie rzeczy rodzajem wariacji na temat mitu orfickiego $\mathrm{z}$ happy endem, przeniesionej ze świata antycznego w inne, bardziej środkowoeuropejskie dekoracje, najwyższe pasmo Sudetów pojawia się jako obszar styku w zupełnie innym wymiarze. Konflikt ukazany w operze ma zupełnie inną rangę niż wszystkie wymienione wcześniej spory: czesko-śląskie, austriacko-pruskie czy katolicko-protestanckie. Nienazwane w libretcie pasmo, identyfikowalne jednak bez problemu dzięki czytelnym motywom historii Ducha Gór i brzmiącym z czeska imionom niektórych postaci, staje się miejscem iście romantycznej akcji, w której przekraczane są zupełnie inne granice. Zły Duch Gór porywa do swego podziemnego królestwa dziewczynę imieniem Alma, córkę władcy Domoslava i narzeczoną młodego rycerza Oskara, który nadaremnie próbuje ją odzyskać i gotów jest — niczym Orfeusz — zejść do podziemnego świata cieni. Dzięki jego nieustępliwości i miłości, wierności i podstępowi Almy, ale także dzięki pomocy operującej równolegle „,niskiej pary” — Trolla i Ludmil- 
ly (niczym Papagena i Papageny w Czarodziejskim flecie Wolfganga Amadeusa Mozarta), z pozoru groźny władca gór zostaje wyprowadzony w pole, a „wysoka para" wraca na powierzchnię, zostawiając za sobą podziemne zaświaty. Poza wspomnianymi już imionami Domoslava i Ludmilly nie ma w tej wersji historii o Duchu Gór żadnych bezpośrednich odniesień natury geograficznej. Przeciwnie — żeńskie imię Alma mogłoby sugerować kontekst alpejski.

Historia Ducha Gór zostaje tu wymieszana z motywem orfickim oraz dodatkowo okraszona licznymi dalszymi odniesieniami do oper barokowych i klasycznych. Tym samym wyniesiona zostaje ponad lokalny i realny kontekst Karkonoszy, niejako emancypując się z pierwotnych ram topograficznych. Jednakże nawet w owej wyabstrahowanej postaci krajobraz górski nie wyzbywa się swojej — jak się wydaje - immanentnej cechy: graniczności — tym razem wolnej od kontekstów politycznych, wyznaniowych, a nawet obyczajowych czy zmysłowych, a sprowadzonych do wymiaru metafizycznego.

\section{Wniosek}

Najwyższe pasmo Sudetów, będące wyraźną granicą geograficzną między Czechami a Śląskiem, staje się tematem piśmiennictwa różnych epok, przy czym poszczególni autorzy zwracają uwagę na różne aspekty karkonoskiej graniczności, które uwypuklają w swych dziełach. Na ową granicę, istniejącą w rzeczywistej przestrzeni geograficznej, nakładają oni w swoich koncepcjach inne, ideologiczne, linie styków lub podziałów cywilizacyjnych, politycznych, konfesyjnych i obyczajowych, w świetle których pogranicze jawi się w wielu wymiarach, nierzadko łączących się z sobą. 